\title{
The use of Betel leaf in Nyirih tradition: Analyzing an ethnoscience-based learning material
}

\author{
Dedi Riyan Rizaldi ${ }^{1,2}$, Yayuk Andayani ${ }^{1}$, Aris Doyan ${ }^{1}$, Muh. Makhrus ${ }^{1}$ \\ Ziadatul Fatimah ${ }^{3}$, Eris Nurhayati ${ }^{4}$ \\ ${ }^{1}$ Master Program of Science Education, University of Mataram, Mataram, Indonesia \\ ${ }^{2}$ MA Plus Nurul Islam Sekarbela, Mataram, Indonesia \\ ${ }^{3}$ SMA NW Mataram, Mataram, Indonesia \\ ${ }^{4}$ SMAN 3 Mataram, Mataram, Indonesia \\ *Corresponding e-mail: dedi0313@gmail.com
}

\begin{abstract}
Nyirih tradition is one of popular traditions in Indonesia, a country with a diverse ethnic groups, cultures, and languages. The traditions are potential to be explored and used as contextual learning materials. This research aims to analyze the relationship between science (physics, biology, and chemistry) on the use of Betel leaf in the Nyirih tradition. This research used an ethnoscience approach, an approach which raises various cultures in a society to become a science learning topic, so that it would be easier for students to integrate various material in science learning with the real-life contexts. It was a qualitative research using the study literature type which consists of several steps, namely: (1) determining the topic, (2) gathering materials as references, (3) making an introduction, (4) determining the method, (5) discussing the findings, and (6) making a conclusion. The results suggest that the use of Betel leaf in Nyirih tradition could become an interesting topic in explaining several concepts in science.
\end{abstract}

Keywords: Betel leaf, ethnoscience, Nyirih tradition, science material

How to cite: Rizaldi, R. Dedi, Andayani, Y., Doyan, A., Makhrus, M., Fatimah, Z., \& Nurhayati, E. (2021). The use of Betel leaf in Nyirih tradition: Analyzing an ethnoscience-based learning material. International Journal on Education Insight, 2(1), 29-36. DOI: $10.12928 /$ ijei.v2i1.3579

\section{INTRODUCTION}

The 21 st-century learning today requires teachers to train various skills that are following the pillars of education, namely learning to know, learning to do, learning to be, and learning to live together (Rizaldi, et al., 2020). The skills in question are in the form of critical thinking skills, communication, creative thinking, and collaboration (Rizaldi, et al., 2019; Zubaidah, 2016). In short, it can be seen that 21 st-century learning seeks to emphasize the learning process must be student-centered, collaborative, contextual, and integrated with society. The development of increasingly advanced culture not only has a positive impact but also has a negative impact, one of which is in the context of local culture which has begun to be forgotten over time. The solution that can be done so that the learning process still refers to the demands of the $21 \mathrm{st}$ century and still preserves local culture can be applied learning with an entoscience approach. This learning raises the culture or habits that occur in people's lives which are then viewed in terms of science (Physics, Biology, and Chemistry) (Andayani, et al., 2020; Fitriani \& Setiawan, 2018).

According to Sudarmin (2015) that the scientific approach suggested in education in Indonesia today is ethnoscience, namely original knowledge in the 
form of language, customs and culture, morals; Likewise, technology created by a particular society or person which contains scientific knowledge. Besides, this approach is a strategy for creating an ethnoscience learning environment and learning planning that integrates culture as part of the science learning process (Rahmawati, et al. 2019). The application of science teaching and learning with an ethnoscience approach requires the ability of teachers to combine original knowledge with scientific knowledge.

Learning science with an ethnoscience approach is expected to be able to change the learning process from teacher-centered to student-centered learning. According to Atmojo (2012), science learning with an approach that connects learning with society's culture can increase students' appreciation of the culture that develops in their area. Besides, ethnoscience-based learning can bridge the combination of student culture and scientific culture in schools and will be able to realize the process of developing the self-quality of elementary school students as the nation's future generation, which is believed to be a major factor for the growth and development of the nation. In the 2013 curriculum to realize the process of character development and the quality of student competencies. Based on this background, one of the traditions that can be used as a study in the science learning process is "The Use of Betel Leaf in Nyirih Tradition". The selection of betel leaf as a topic in learning is because the context of betel leaf that is understood by the public tends to be information obtained from previous generations without paying attention to its impact from a scientific perspective. So that by applying the ethnoscience learning model, it is hoped that readers will be able to thoroughly understand the benefits of betel leaf scientifically and it is useful to improve students' analytical skills in connecting one topic to several disciplines during the learning process.

\section{RESEARCH METHOD}

This research is a type of qualitative research in the form of a literature study. Library research is not only a first step in preparing a research framework but can also be used as a source to produce research data (Fuadi, et al., 2020). The type of data collected is secondary data obtained from various written sources such as articles, documents, and other sources according to the research topic of betel leaf which is used during the process of Society Nyirih Tradition. The data taken were obtained by reviewing the results of research that had already been carried out to be used as a reference in answering the objectives of writing this article. There are at least five steps that need to be considered in conducting literacy studies according to Setyosari (2013), they are as follows.

\section{Determining the topic}

The research topic is the initial part that needs to be done in conducting a research. This is because with the topic, the research will be more focused. In determining the topic, several considerations need to be considered, especially related to the variables to be observed. In addition, in writing this article the topic is used can be integrated with the concepts contained in science subjects at the junior high school level.

\section{Gathering materials}

Collecting a variety of relevant references is needed to develop the topic of the problem. In addition, the existence of relevant information sources can support and increase readers' confidence in the results of the research that has been done. The references used in the writing of this article use various sources 
related to the ethnoscience learning model, the characteristics of betel leaf, and the use of betel leaf in society Nyirih tradition in terms of science.

\section{Making an introduction}

The introduction is developed to provide the reader with a brief overview of information regarding the topic of the research being carried out. In writing the introduction, there are several things that need to be considered, such as the reasons for taking the topic, the purpose of the research, and the role or benefits of doing research related to that topic in the learning process because the study in this article is more focused on the world of education.

\section{Making a discussion}

The discussion is written with the aim of explaining various findings in research accompanied by various supporting theories to strengthen the research results that have been obtained.

\section{Making a conclusion}

The final part of a study is a conclusion that contains a summary of the research topic. Conclusions can provide the final result to the reader regarding whether or not the objectives of the study have been achieved.

\section{RESULTS AND DISCUSSION}

\section{Ethnoscience approach}

Ethnoscience is a learning approach that elevates the culture of an area or local wisdom traditions as study material in the learning process. According to Rahayu and Sudarmin (2015) that an ethnoscience is an approach or activity that transforms knowledge developed in society (native science) into local cultural science (scientific science) related to the material being studied. In this approach, students do not only see science as a foreign culture that must be studied in the classroom but also local culture or wisdom that they already recognize in everyday life. The application of learning with the ethnoscience approach is expected to be able to develop learning methods that are generally still teacher-centered into student-centered learning. Thus it can increase students' appreciation of local wisdom culture or traditions and create contextual and meaningful learning (Novitasari et al., 2017).

\section{Nyirih tradition}

Nyirih tradition is a tradition that almost exists in most regions in Indonesia. This tradition is usually carried out by the society as a side activity to fill their spare time besides after eating. The habit of chewing has been going on for a long time and has become a symbol for the indigenous Malay people (See Figure 1 ). The nyirih process is usually served to all guests who attend traditional ceremonies in most parts of Indonesia, such as wedding ceremonies, births, deaths, and healing. However, the longer the process of nyirih has become a daily habit for people to fill the time gap (Kamisorei \& Devy, 2017). 

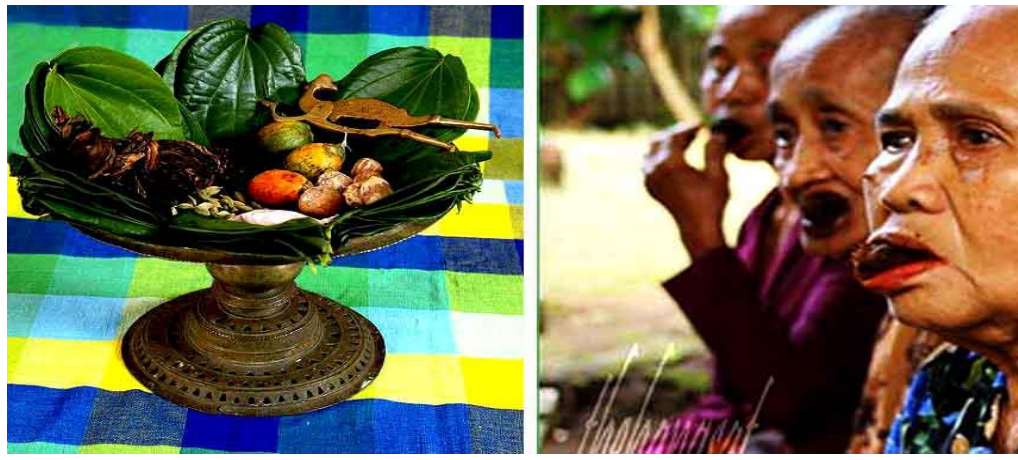

Figure 1. Nyirih Tradition in Society (Central News, 2017)

Commonly used betel leaf ingredients are betel leaf, areca nut, gambier, tobacco, and other natural ingredients. Society knows that the ingredients that exist in nature have very abundant benefits for them, both in terms of health and in terms of customs that develop in people's lives, especially in rural areas. Also, the materials used are easy to obtain. Parianti and Ariyasa (2015) state that the betel plant is very easy to find in Indonesian areas so that people who have the habit of chewing betel leaves do not find it difficult to get it because most people have betel plants around their homes.

\section{Ethnoscience analysis in science learning process}

\section{Ethnoscience concept}

Cleanses and protects the condition of the mouth through the Nyirih process by utilizing natural ingredients such as betel leaf, areca nut, gambier, and whiting.

Original science (Beliefs that develop in society)

Initially, the Nyirih process that developed in society was only an important part of traditional ceremonies and religious ceremonies. This understanding then influences the society that the ingredients for the Nyirih process have good properties so that people slowly start chewing outside of official events and over time it becomes a habit that creates pleasure and feelings of pleasure making it difficult to let go. Besides, people also think that beetling can strengthen teeth, eliminate bad breath and nourish gums.

\section{Local cultural science}

Aspects of Physics

The physical aspects in terms of nyirih activities can be seen when ingredients such as betel leaf, lime, gambier, etc. are mixed and then crushed in the container provided. However, in most of the society, this process does not use a mashing tool but instead directly puts the mixture of ingredients into the mouth and then chews it. In the collision process, there is a physical change in terms of changes in the size of the substance. This physical change is caused due to direct friction with substances such as the process of cutting, pounding, and so on, causing only the size to change while its properties remain. 


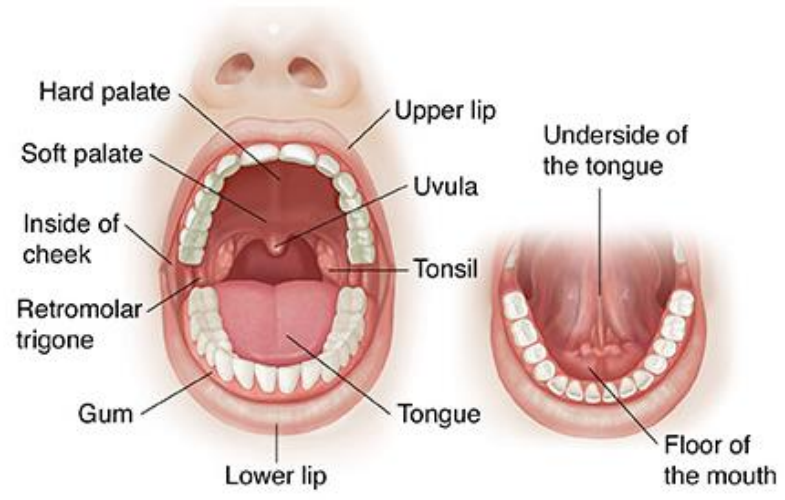

Figure 2. Organs of the physical digestive system in the human mouth (World of Life Sciences, 2019)

Various physical processes that occur in the human mouth can help students learn related concepts of pressure such as surface area, compressive force, and other terms learned in Grade VIII.

Aspects of Biology

Betel is a type of plant that has leaves with a single morphology in the shape of a heart, pointed tips, grows alternately, has a distinctive smell when squeezed, has a length of about $5-8 \mathrm{~cm}$ and a width of $2-5 \mathrm{~cm}$ (Astuti, 2011). The use of betel as a medicinal ingredient has a strong basis because of the content of essential oils which are natural phenolic components and can function as an antiseptic, antioxidant, and fungicide (Moeljanto, 2003). The content contained in 100 grams of betel leaf can be seen in Table 1 .

Table 1. Content in 100 grams of Betel leaf

\begin{tabular}{lc}
\hline \multicolumn{1}{c}{ Content } & Amount \\
\hline Water & $85.4 \mathrm{mg}$ \\
Protein & $3.1 \mathrm{mg}$ \\
Carbohydrate & $6.1 \mathrm{mg}$ \\
Fiber & $2.3 \mathrm{mg}$ \\
Iodine & $3.4 \mathrm{mg}$ \\
Mineral & $2.3 \mathrm{mg}$ \\
Calcium & $230 \mathrm{mg}$ \\
Phosphor & $40 \mathrm{mg}$ \\
Iron ion & $3.5 \mathrm{mg}$ \\
Vitamin A & $9600 \mathrm{IU}$ \\
Potassium nitrate & $0.26-0.42 \mathrm{mg}$ \\
Thiamin & $70 \mathrm{mg}$ \\
Riboflavin & $30 \mathrm{mg}$ \\
Niacin & $0.7 \mathrm{mg}$ \\
Vitamin C & $5 \mathrm{mg}$ \\
Cassava fluor & $1.0-1.2 \%$ \\
Non reduce sugar & $0.6-2.5 \%$ \\
Reduce sugar & $1.4-3.2 \%$ \\
\hline
\end{tabular}


Essential oil, which is one of the ingredients in the betel leaf can act as antibacterial, due to the presence of phenolic compounds that can change the properties of proteins. The phenolic compounds in question are catechins and tannins which are known to inhibit the biological activity of Streptococcus mutants which are the dominant bacteria that cause caries in teeth (Supomo, 2017). This is supported by research conducted by Wilis and Anriyani (2017) which shows that betel leaf juice contains a bactericidal compound that kills Streptococcus mutants and inhibits plaque formation which can lead to dental caries.

By identifying the shape, function, and role of betel leaf for humans in real life, it can provide students with an overview of the many benefits of betel leaf that humans can use. Of course, in addition to increasing students 'understanding of the concept of plant structure and function studied in grade VIII, it can also train students' gratitude that every living thing has benefits for other living things.

Aspects of Chemistry

Subconsciously, what people do regarding the betel process can be explained from a scientific perspective. When the betel leaf mixture is chewed in the mouth, there will be a process of adjusting the level of acidity $(\mathrm{pH})$ in the saliva. The normal $\mathrm{pH}$ value in saliva itself ranges from 5.5 to 6.5. Foods that enter the mouth, especially those containing carbohydrates, can cause a change in the $\mathrm{pH}$ value of saliva due to bacterial fermentation. Decreasing salivary $\mathrm{pH}$ can increase the risk of high caries while increasing $\mathrm{pH}$ can increase calculus formation / tooth crust (Rahmawati, 2015). According to research conducted by Soesilo, the degree of acidity $(\mathrm{pH})$ of saliva will be maximized to inhibit bacterial growth between $6.5-7.5$ and if in the oral cavity it has a low $\mathrm{pH}$ level between 4.5 - 5.5 it will facilitate bacterial growth (Pradanta et al. 2016).

The chewing process that occurs in the betel leaf activity can stimulate the salivary glands and then through chemical stimulation such as the bitter and chewy taste produced by the compound ponifenol (one of the ingredients in betel leaf) can increase the secretion process, causing increased salivary flow and of course the salivary buffer capacity will also increase. This is because the buffer capacity correlates with the salivary flow rate so that the process of increasing the saliva buffer can restore the $\mathrm{pH}$ to normal conditions more quickly. According to research conducted by Haroen in Pradanta \& Khatimah (2016) states that the chewing process is a mechanical stimulus that stimulates an increase in salivary secretion while the taste is sensory information related to chemical stimuli that can increase the speed of salivary flow.

As the explanation above, it can be seen that the Nyirih process which is often carried out by the community can explain the chemical reaction process, especially related to the terms acid, base, and salt which were learned by students in grade VII

\section{The integrity between physical, biological, and chemical sciences}

Based on the descriptions related to each aspect that can be learned from the betel process, it gives students an idea that basically every process that occurs in humans cannot be separated from physics, biology, and chemistry. All these aspects support one another. So that by using ethnoscience learning, students will be able to learn the concept as a whole. This is in accordance with the actual context of science learning. By getting used to students to integrate a

IJEI, Vol. 2, No. 1, April 2021, 29-36 
phenomenon, especially various habits that occur in community life, students will appreciate and maintain habits, customs, or other activities. Meanwhile, from the aspect of learning outcomes, of course this will practice students to get used to thinking critically, looking for various information, and finding solutions to existing problems.

\section{CONCLUSION}

Local culture can be used as very interesting material to be used as a topic in the science learning process. One such topic relates to the use of betel leaf in the nyirih process which is often practiced by Indonesian society. Betel leaf has various benefits that can be attributed to the context of science material (physics, biology, and chemistry). With the ethnoscience learning approach, it is expected to be able to provide opportunities for students to connect the concepts learned with things that are contextual or become habits in people's lives.

\section{REFERENCES}

Andayani, Y., Purwoko, A. A., Jamaluddin, J., Makhrus, M., \& Harjono, A. (2020). Identifikasi pemahaman guru tentang pengembangan perangkat pembelajaran IPA SMP dengan pendekatan etnosain. Jurnal PEPADU, 1(2), 229-234.

Astuti, I. P., \& Munawaroh, E. (2011). Karakteristik morfologi daun sirih merah: Piper crocatum Ruiz \& Pav. dan Piper porphyrophyllum NE Br. koleksi Kebun Raya Bogor. Berkala Penelitian Hayati, Edisi Khusus A, 7, 83-85.

Atmojo, S. E. (2012). Profil keterampilan proses sains dan apresiasi siswa terhadap profesi pengrajin tempe dalam pembelajaran ipa berpendekatan etnosains. Jurnal Pendidikan IPA Indonesia, 1(2), 115122.

Central News. (2017). Tradisi Nyirih dalam Masyarakat. Retrieved form https://centralnews.co.id/2017/07/27/fakta-menarik-tentang-papuapulau-paling-timur-nkri/2-5/.

Fitriani, N. I., \& Setiawan, B. (2018). Efektivitas modul IPA berbasis etnosains terhadap peningkatan keterampilan berpikir kritis siswa. Jurnal Penelitian Pendidikan IPA, 2(2), 71-76.

Fuadi, H., Robbia, A. Z., Jamaluddin, J., \& Jufri, A. W. (2020). Analisis faktor penyebab rendahnya kemampuan literasi sains peserta didik. Jurnal Ilmiah Profesi Pendidikan, 5(2), 108-116.

Kamisorei, R. V., \& Devy, S. R. (2017). Gambaran kepercayaan tentang khasiat menyirih pada masyarakat Papua di Kelurahan Ardipura I Distrik Jayapura Selatan Kota Jayapura. Jurnal Promkes: The Indonesian Journal of Health Promotion and Health Education, 5(2), 232-244.

Moeljanto, R. D. (2003). Khasiat \& manfaat daun sirih: Obat mujarab dari masa ke semasa. AgroMedia.

Novitasari, L., Agustina, P. A., Sukesti, R., Nazri, M. F., \& Handhika, J. (2017). Fisika, etnosains, dan kearifan lokal dalam pembelajaran sains. Prosiding SNPF (Seminar Nasional Pendidikan Fisika) (pp. 81-88).

Parianti, N. W., \& Ariyasa, I. G. (2015). Hubungan kebiasaan menyirih terhadap kejadian karies gigi pada lanjut usia di Desa Batubulan Kangin. VIRGIN: Jurnal Mmiah Kesehatan dan Sains, 1(2).

Pradanta, Y. E., Adhani, R., \& Khatimah, I. H. (2016). Hubungan kadar pH dan volume saliva terhadap indeks karies masyarakat Menginang Kecamatan 
Lokpaikat Kabupaten Tapin (Studi observasional dengan pengumpulan saliva metode spitting). Dentino: Jurnal Kedokteran Gigi, 1(2), 51-56.

Rahayu, W. E., \& Sudarmin, S. (2015). Pengembangan modul IPA terpadu berbasis etnosains tema energi dalam kehidupan untuk menanamkan jiwa konservasi siswa. Unnes Science Education Journal, 4(2).

Rahmawati, I., Said, F., \& Hidayati, S. (2015). Perbedaan pH saliva antara sebelum dan sesudah mengkonsumsi minuman ringan (Studi pada siswa Kelas II dan III Madrasah Ibtidaiyah Zam-Zam Zailani Banjarbaru Kalimantan Selatan tahun 2014). Jurnal Skala Kesehatan, 6(1).

Rahmawati, S., Subali, B., \& Sarwi, S. (2019). The effect of ethnoscience based contextual learning toward students' learning activity. Journal of Primary Education, 8(2), 152-160.

Rizaldi, D. R., Makhrus, M., \& Doyan, A. (2019). Analisis tingkat kemampuan berpikir kritis dengan model perubahan konseptual ditinjau dari gaya belajar siswa. Jurnal Pendidikan Fisika dan Teknologi, 5(1), 74-81.

Rizaldi, D. R., Nurhayati, E., \& Fatimah, Z. (2020). The correlation of digital literation and STEM integration to improve Indonesian students' skills in 21st century. International Journal of Asian Education, 1(2), 73-80.

Setyosari, P. (2013). Metode Penelitian Pendidikan \& Pengembangan. Jakarta: Prenadamedia Group.

Sudarmin. (2015). Pendidikan Karakter, Etnosains Dan Kearifan Lokal. Semarang: Swadaya Manunggal.

Supomo, F. D. S. (2017). Pengaruh ekstrak daun sirih merah (Piper cf. fragile Benth.) terhadap bakteri penyebab sakit gigi. Ekologia: Jurnal Ilmiah Ilmu Dasar dan Lingkungan Hidup, 11(1), 30-35.

Wilis, R., \& Andriani, A. (2017). Efektifitas berkumur rebusan daun sirih dibandingkan rebusan daun saga terhadap perubahan derajat keasaman air ludah. AcTion: Aceh Nutrition Journal, 2(1), 67-72.

World of Life Sciences. (2019). Organs of the Physical Digestive System in the Human Mouth. Retrieved form https://worldoflifesciences.com/ human-digestive-system.

Zubaidah, S. (2016, December). Keterampilan abad ke-21: Keterampilan yang diajarkan melalui pembelajaran. Seminar Nasional Pendidikan (Vol. 2, No. 2, pp. 1-17). 